\title{
Moses Hahl: \\ Finnish-American Disciple of Marx, Darwin and Nietzsche
}

\author{
By Arja Pilli \\ University of Turku
}

\section{A Man of the Labor Movement}

The name of Moses Hahl is closely associated with the first decades of the Finnish-American labor movement. This man, born in the East Finland parish of Liperi in 1879, received little formal education, did casual labor and became familiar with socialism before he moved to America in 1903. After his migration, he participated in the organizational work of the Finnish Socialist Federation and circulated throughout the continent establishing local socialist units among emigrants and giving lecture courses on socialism, materialism, history and social issues. For example, in 1906, Hancock, Michigan, was the site of courses for which the speakers included Hahl, who treated economics, sexual matters and the Socialist Party program. ${ }^{1}$

Hahl's contemporary, F.J. Syrjälä, one of the leading figures in the Finnish-American socialist movement, characterized Hahl as follows:

The toughest and most energetic of the agitators of that era was Moses Hahl, who was also the most fearless and most self-informed. He wandered from town to town and city to city with whatever provisions he was able to obtain. Some units pooled a few dollars, took up a collection, which rarely produced funds worth mentioning. They were insufficient for the traveler's food, housing or transportation. However, travel was modest. Sometimes a farefree freight train. The agigator would obtain a place to stay and even a meal from a comrade. To a few narrow and fanatic rankand-file, this appeared to be a comfortable life's career. Keep a careful account of where you received a collection, where money for travel. A goodly sum could accumulate, it was thought. And there were no expenses either, since comrades provided room and board. And if the agitator's record book had been lost in the discomfort of the train, so that he could not recall how many cents had come from each collection, there were those who began to make accusations about using the ideology for swindling. ${ }^{2}$

For most of his years in America, Hahl was editor of socialist newspapers. 
As early as 1905 he had edited the satirical publication, Velosuu; in 1906 he had become a full-time agent of the Socialist Federation, and in 1907 editor of Raivaaja (The Pioneer) in Fitchburg, Massachusetts, and later of Työkansa (The Workpeople) in Port Arthur, Ontario. In 1914 he switched to the chief editorship of Työmies (The Worker) in Superior, Wisconsin, and in 1917 returned to Raivaaja as editor. During his career, he frequently had differences of opinion with his colleagues and ideological comrades, but the reasons seem to have been largely personal. Hahl's ideological line did not generally provoke criticism, since he sought to follow the Socialist Party line. When Finnish-American Socialists divided into Social Democrats and Communists after the Russian Bolshevik Revolution, Hahl gave his support to the former. Raivaaja, the staff of which then included Hahl, also continued to pursue the same position after Työmies became Communist. Hahl spent the last years of his life as a farmer, continuing his literary efforts far from the maelstrom of politics. Hahl died in $1928 .^{3}$

Hahl's influence on the Finnish emigrant socialist movement is evident in many areas: agitation and organization, the press and literature. Hahl's work as a writer may be divided basically into three separate categories, which are, however, closely interrelated in terms of ideology: 1) nonfiction expressing a world view, 2) serious ideological fiction and 3) humorous output. Hahl published many works, but socialist newspapers and periodicals were also an important medium for his efforts.

The first category includes the following works;

Uudempi kansantalous (1906) (Modern Economics)

Alkuoppi lapsille (1907, published in condensed version in 1910 in Finland as Sosialistinen lasten aapinen) (Primary Education for Children)

Aseellinen vallankumous (1909, Finland 1910) (Armed Revolution)

Lihan evankeliumi (1914) (The Gospel of Flesh)

Kehitysopin aakkoset (1919) (The Elements of Evolution)

It is perhaps surprising that a man with only an eight-month primary school education published such a significant amount of exposition. Indeed, many contemporaries remember $\mathrm{Hahl}$ as a knowledgeable, wellread man.

Hahl's serious literary output includes poetry collections Punaista (Red) (1906) and Langenneen lauluja (Songs of the Fallen One) (1918) as well as the plays "Tumma täplä" (The Dark Spot) (1912) and "Punakaartilainen" (The Redguardsman) (1919) and an at least semi-autobiographical novel, Maansa hylkimiä (Outcasts of Their Land) (1927). Hahl published his humorous output under the pseudonym "Hijoppi 
Rotilainen," which he also used for his newspaper columns. This category included the story collections Juttuja I - II (Tales I - II), Agitaattori Räyhäsuu (Agitator Räyhäsuu), Jumalan karitsat (The Lambs of God) and a satirical play, "Uskovia aaseja" (Pious Asses).

The above tripartite division into categories is not entirely appropriate. Hahl's output was particularly unified in content. Virtually all his literary efforts are tendentious, and the overarching ideas are the principles he treats in his nonfiction works. Even behind his humorous tales he is disclosed as the single-minded agitator, whose satirical whip punished all the abuses, prejudices and institutions against which he struggled.

Moses Hahl (alias Hijoppi Rotilainen) was an active promulgator of socialism, and the socialist wellspring also forms the major current running through his works. What makes him different from other labor writers is that the socialist wellspring draws together two other strong perspectives - influences from Darwinism and, what is most peculiar, from the ideas of Friedrich Nietzsche. In the latter part of my article, I shall analyze this unique conceptual conglomeration. Hahl's inter- pretation of socialism will go largely untreated in this connection.

\section{Influences from Nietzsche and Darwin}

As a lecturer and a newspaperman, Hahl had to increase his store of knowledge and so he familiarized himself not only with socialist theory but also other contemporary intellectual currents that had reached the reading public in Finland and America. He was acquainted with the writings of Tolstoy, Darwin and Nietzsche.

In the 1890's, Finnish intellectual circles became familiar with Nietzsche's philosophy, which generated a kind of fad phenomenon among a portion of the student youth. Moses Hahl did not belong to these circles, but it is possible that he became aware of this current while still in Finland or through articles in Finnish or works translated into Finnish. ${ }^{4}$ Hahl first treated Nietzsche's philosophy in the 1909 Köghälistön Nuija article, "Yli-ihminen" (Superman). This was, however, based on influences from George Bernard Shaw and critical comments about them. ${ }^{5}$.

The following year, Hahl published in Köyhälistön Nuïja a rather extensive article, "Kristus, Kristitty ja ihminen" (Christ, the Christian and Man); which, he revealed, was based primarily on Nietzsche's ideas. In a footnote, however, he declared that "in order to avoid any misunderstandings," he did not entirely accept Nietzsche's philosophy, especially not "the intellectual aristocracy carried to its extreme" and "the caste 
politics."6 The play, "Tumma täplä," (1912) considers the possibilities of a superman in a world of misery, and this play clearly reflects the influence of both Nietzsche and Darwin, evidently along with Shaw's example. ${ }^{7}$ Influences drawn more extensively from Nietzsche appear in 1914 in Lihan evankeliumi. Moraalin arvostelua (The Gospel of Flesh: A Critique of Morality) - a curious and surprising work both in terms of its subject and its thought process. ${ }^{8}$

Friedrich Nietzsche's contradictory, abstruse philosophy has given impetus to adherents of many different ideological orientations. His ideas have been searched for support by conservatives and even national socialists and fascists, but also certain leftists. Nietzsche's raw, virtually poetic manner of expression made possible diverse interpretations, and he has frequently been misunderstood. ${ }^{9}$ As such, it is not unusual that he should acquire an enthusiastic disciple from socialist ranks, but it is unique that a professional socialist agitator, a self-taught common man, should become enthusiastic about the ideas of an aristocratic esthete. Hahl's output reflects many different influences from Nietzsche. Most directly, he embraced the concepts of morality, life force and attitude towards religion, particularly Christianity. The most problematic point was the superman doctrine, which Hahl responded to ambivalently. Obviously, he was well aware that it was not appropriate for a Marxian socialist to accept the superman doctrine. Nevertheless, he has given the matter extensive consideration in his writings, which is indicative of great interest.

Hahl's relationship to Darwin was more direct and less troublesome than this relationship to Nietzsche, since he could accept Darwinism as such. The theory of evolution fits well into the materialistic world view of socialists and into a general opposition to religion. Hahl was personally interested in the biological sciences. In 1919, he published a rather extensive and detailed textbook, Kehitysopin aakkoset, which was intended for the education of Finnish emigrant children, especially for use in the socialist Ihanne liitto schools. There is no information available as to how widely this work was used. Hahl wanted to provide the young generation with the elements to construct a modern image of the world and to destroy the false images taught by the Christian church. $\mathrm{He}$ regarded the new biologically scientific image of the world as important in the building of a new society and in the intellectual liberation of the working class. ${ }^{10}$

Kehitysopin aakkoset is essentially a factual, quite detailed, perhaps even rather difficult work. Hahl's own comments appear more nearly in the preface and in the conclusion. In the preface, the writer acknowledged 
a group of experts, e.g. Haeckel, perhaps the best known popularizer of Darwin, and a Finn, A.J. Mela, who was among the first disseminators of evolution theory in Finland. It is significant that he did not mention having benefited from a direct reading of the works of Darwin.

\section{Human Refinement}

In his 1909 article, "Yli-ihminen," Hahl proceeded from Bernard Shaw's view that ordinary humans are not capable of establishing and maintaining a socialist society, that this task demands superman, whose siring and bearing should be entrusted to the most physically and intellectually healthy individuals. In his own commentary, Hahl condemned such extreme ideas. On the one hand, Hahl believed in the possibilities for ordinary humans, the proletariat, to make revolution and to improve their living conditions, assuming that the proletariat's class spirit has been awakened and class energy generated. On the other hand, he rejected the idea of a superman. Although Herculeses and Minervas might be found to bring into existence such a select individual, he would nevertheless be overcome in a society full of beguiling serpents and tempting fruits. Instead, Hahl claimed optimistically to believe in human capacity for improvement. Man could become refined as society became better and more just. 11

The same basic idea is repeated in Lihan evankeliumi, although somewhat obscured by many generations of secondary themes. Hahl felt that the building of the future was founded on the conscious improvement of the working class. The concept of refinement is not unambiguous nor clear, perhaps for the very reason that he has incorporated influences from various sources, and these sources are not themselves unambiguous. For Hahl, refinement appears to be above all a function of a changing society, but in Lihan evankeliumi and "Tumma täplä" he also focuses attention on the biological refinement of the human species, going so far as to write of purification of the blood;

Insofar as permitted by body structure, man has no natural limits on his ability to develop, only social ones of a material and moral nature.

Society's great material and moral transformation will affect the development of the individual to the extent that he may be said to be a new man. ${ }^{12}$

Hahl's ideas concerning human refinement might well have been influenced by Nietzsche. Nietzsche preached the superman's capacity for refinement, by which he meant more precisely intellectual refinement, the genesis of the genius, the creative select individual. Researchers have not agreed on the extent to which Nietzsche's refinement concept is 
related to Darwin's theory of evolution. From time to time, he was clearly interested in Darwinism, but it was peripheral to his thought, and later he totally condemned it. ${ }^{13}$ Hahl's concept of refinement was different. We was a socialist and a Darwinist. He awaited the collective awakening of the working class to its potential for refinement, and through this he believed that society would be transformed. Similarly, he believed that the socialist society would come into existence peacefully and not through violent revolution. ${ }^{14}$

Using the theory of evolution as a foundation, Hahl argued that humanity must change, since the existence of every species depended on its defensive and adaptive abilities. The potential for refinement was only for the fittest and the strongest, only for the ascendant class, the proletariat, not for the decadent bourgeoisie. ${ }^{15}$ His concepts of the development of a superior human species and a superior society are also reminiscent of social Darwinism in a modified form; i.e., no hope rests on the well-to-do bourgeois middle class, but rather the future is seen as belonging to the healthy proletariat, the emiserated, who, according to Spencer, were doomed to remain under the feet of the successful. Ridicule of bourgeois decadence might well be a feature Hahl had borrowed from Nietzsche; conversely, the demands Hahl made for social change were completely foreign to the philosophy of superman.

$\mathrm{Hahl}$ did not detail what he expected from human refinement. $\mathrm{He}$ was nonetheless, more interested in the refinement of the body than the mind.

Where the gospel of flesh is preached and the healthy body respected, there is preached life, refinement, strong and beautiful life. ${ }^{16}$

Furthermore, Hahl did not attempt to conjure up the society of the future, although he viewed the elimination of exploitation as an important element. Instead, he depicted in an often exaggerated, abhorrently realistic tone his society's filth, injustice, sickness and poverty, under which the weakest members of the proletariat sink, unable to arise. Hahl was a stern architect of the future: along the road to a new social order and a better life the decadent classes and slum-emiserated dregs would grow weary. Despite all his depictions of misery, he still trusted in finding healthy proletarians, who would have life force, and he also believed that the correct measures might give health to the products of the slums.

In Lihan evankeliumi, Hahl returned to ideas of Shaw that he had earlier criticized in his article. He demanded that the bringing of 
children into the world be entrusted to those individuals whom the doctor found to be healthy in all respects. Moreover, the rearing of children should become a function of society. ${ }^{17}$

The same merciless view of human evolution and the same manner of linking social and biological changes are also apparent in the conclusion of Kehitysopin aakkoset. Hahl affirmed that nature had evolved humanity over millions of years of time, but there still lived people on earth whose knowledge or skills were somewhat inadequate, or who were unhealthy. Hahl had no use for the diseased; they had no potential for development. There was, however, still hope for those to whom hard work or poor living conditions did not leave time or energy to care for and develop themselves. ${ }^{18} \mathrm{Hahl}$ did not continue his train of thought on the necessity of social change, but the conclusion itself was an obvious suggestion in that direction.

Moses Hahl put his superman musings in literary form in his cưrious play, "Tumma täplä. Yliihminen ja aliihminen." (The Dark Spot: Superman and Subman). The central characters are Superman, a member of the rising working class and carpenter-writer, and his beloved, whose duty it is to produce a new, healthy citizen and to improve the human race. In Shaw's play, Man and Superman, the underlying idea is also that an intelligent man and a beautiful woman are appropriate parents for a superman. Otherwise, Shaw's drawing room comedy and Hahl's macabre drama have little in common. Also appearing in Hahl's play is a well-meaning cellular researcher, a doctor, who is to confirm the fitness of the candidates for father and mother. As manifestations of decadence, ignorance and filthiness, the play trots out an assortment of sub-humans, portrayed with loathing by Hahl. There is a down-and-out alcoholic, a prostitute, a cripple, a bureaucrat, a madman, "a servant of death" or priest, and a "moonstruck poet," the son of the priest and suffering from syphilis. Faithful to Nietzsche's philosophy, the play's Superman claims that empathy is a crime, since the emiserated herd is doomed to destruction: according to him, life is "dirty grey, but it will change to the extent that the healthy and the strong create a new people." At the end of the play, it turns out that he himself has unknowingly contacted syphilis. Apparently, Hahl has used his play to say that superman is impossible in a world decaying in evil. "Tumma täplä" is more pessimistic than Lihan evankeliumi and the article "Yli-ihminen," since in this play Hahl left no possibility for individuals to rise from the morass. ${ }^{19}$

In summarizing the above, it can be seen that the conditions for the betterment of society and the refinement of humanity are central to 
Moses Hahl's literary output. The necessity for the transformation of society and for holding out the hope of raising working class consciousness are both general pre-conditions for socialism. Hahl's view is undeniably also Darwinist; it might be characterized as Darwinian-based socialism. Conversely, ideas about the development of the human race are foreign to socialist literature, and they are only superficially reminiscent of Nietzsche's superman philosophy. Hahl's exemplar has evidently been Bernard Shaw, who, as a socialist, similarly incorporated influences from evolution theory and superman theory and who also treated race purification.

\section{Against Christian "Decadent Morality," for Life Force}

Through Moses Hahl's entire output, including his humorous stories, a central theme is criticism of religion, church, priests, believers and morality. In Lihan evankeliumi, he focused a great deal of attention on a critique of morality and religion, and in this he was closer to Nietzsche than he was in the superman theory. Evidently, it was easier for him to accept the anti-Christian part of Nietzschean philosophy, because, "as a socialist, he too responded negatively to religion. Hahl differed from another Finnish-American socialist, Matti Kurikka, who influenced by Leo Tolstoy, condemned the church and the clergy, but did not extend his condemnation to religion and, more directly, to the Christian religion. According to Hahl, people should abandon religion altogether; Tolstoyism was for him "half pagan" and "half religious," "in principle, petit bourgeoisism carried to its extreme and, in practice, tending to benefit capitalism and harm the working class." 20

Influenced to a large extent by Nietzsche's ideas, Hahl published his 1909 article, "Christ, the Christian and Man," which is contained in slightly modified from in Lihan evankeliumi. In it, Hahl treated the existence of Christ and concluded that he was an alienated, spiritual human and not the Son of God. According to Hahl, the Christian faith is antithetical to humanity's progress, a life-denying movement, which does not focus on the growth of the healthy person, but the sick. The church had perverted the Christian religion, and, together with the bourgeoisie, wished to keep man down. With support from Nietzsche, Hahl attacked all phenomena of life which he held to be polluted by the humiliating, degenerate Christian morality. He condemned Christian marriage, the system of rearing children, laws and art. He did not condemn morality as such, since the ascendant class was to have a high morality, unlike Christian morality. These musings about morality include very centrally the concept of the life force; which is borrowed 
from Nietzsche. In describing the society of his time, Hahl argued that Christian morality smothered this healthy life force. On the whole, he opposed "the gospel of the spirit" preached by clergy and moralists. In its place should be the gospel of the body, which preached life, refinement, a powerful and beautiful Dionysian experience. ${ }^{21}$ The ambiguous conclusion of Lihan evankeliumi contains Hahl's bombastic critique of the denial of life:

For as the heavens are higher than the earth, so is the gospel of flesh higher than the gospel of the "pure spirit."

Where the gospel of the pure spirit is preached, there will be rejection of social and individual measures for the refinement of the body.

Where the "resurrection of the soul" is preached and the body is ridiculed, there is preached decay and death.

Let everyone know that only the fittest, the strongest, can develop to a higher stage and survive. ${ }^{22}$

In treating religion, Hahl concluded with an overstated, hostile appeal: of primary importance for him was the complete destruction of the Christian faith and of Christians. Every society that wished to be civilized should protect its youth from the effects of the Christian religion. ${ }^{23}$ Similar overstatement in response to religion and Christian circles is also evident in Hahl's columns published under the pseudonym, "Hijoppi Rotilainen." For example, in his serial, "Wiljami Tolvana eli Kristuksella ratsastava aasi" (The Ass Riding Christ), he told of an illiterate peasant who goes to Finnish-Americans as a priest and experiences all manner of strange misadventures through his own stupidity.24 In the novel, Maansa hylkimiä (Outcasts of Their Land), there appears a hypocritical, good-for-nothing priest who joins forces with the capitalists to recruit scabs for a factory being struck. 25

Moses Hahl was perhaps the most brazen Finnish-American proponent of atheism. His literary opposition to Christian faith and church had obvious purposes. Firstly, the writer sought to root out religion from the minds of his readers, and, secondly, he wished to expose as absurd, duplicitous and reactionary the churches - those organizations which most strongly competed with the socialist movement for FinnishAmerican membership. In strong, often overstated language, Hahl tried to clear from the path of socialist progress both intellectual and institutional obstacles. Friedrich Nietzsche's anti-Christianity and antiChristian morality thus suited his purposes well, and Nietzsche's ideas were also clearly a source of inspiration to Hahl. Similarly, Darwin's theory of evolution was an instrument by which Hahl could shake the child-like faith of his readers and listeners. 
Moses Hahl followed enthusiastically and receptively the intellectual currents of his time and brought together, sometimes uncritically, the various strains influencing him. As a professional in the labor movement, he sought to keep socialism as the framework of his manifesto; he demanded the transformation of society as he set his hope on the ascendant working class. For him, the evolution of society included the evolution of the human species. The future belonged to healthy, lifeaffirming proletarians, who had freed themselves from the exploitation of capitalism and from the chains of Christian morality. Sometimes, Hahl's thought pattern exhibited some very odd characteristics. In both Finnish-American and Finnish labor literature, his works on superman and race refinement are solitary exceptions.

Sometimes improvising freely, Moses Hahl popularized Marx, Darwin and Nietzsche for Finnish immigrants. It is difficult to judge how Finnish immigrants responded to Hahl's works on human refinement. His contemporary and debate opponent, Kalle Rissanen, criticized him in particular for his admiration of Nietzsche. ${ }^{26}$ Apparently, this facet continued to be fairly unrecognized in his manifesto. While his atheism fitted seamlessly into the opposition to the church prevalent in circles of the socialist movement, non-socialist immigrants were wary of him and his works, if for no other reason than that they were written by a socialist agitator and atheist.

Although Moses Hahl is one of the best-known Finnish-American writers and journalists, he is no longer remembered as a disseminator of Nietzsche's influence or as a synthesizer of an idiosyncratic scheme of ideas. His posthumous reputation is based on a greater extent on his activity in the labor movement.

(Translated by Gary London)

\section{NOTES}

1. Hahl attended school in Finland for eight months prior to working at such jobs as herdsman, shoemaker's apprentice, office boy, and machinist, which vocation he also practiced for a short time in America. For biographical information, see Köyhälistön Nü̈ja, 1910, p. 164; Elis Sulkanen, Amerikan Suomalaisen Työväenliikkeen historia, Fitchburg, Mass., 1951, passim, esp. p. 487; Bibliophilos 1962: No 3, Esko Häkli, Amerikansuomalaisten kaunokirjallisuudesta ja kustannusoloista, pp. 64-65.

2. F.J. Syrjälä, Historia-aiheita Ameriikan Suomalaisesta Tÿöüenliikkeestä, Fitchburg, Mass. (n.d.), p. 67. 
3. Raivaaja 29 October 1928; Sulkanen op. cit., pp. 169, 229, 317-318; Arja Pilli, The Finnish-language Press in Canada, 1901-1939. A Study in the History of Ethnic Journalism. Annales Academiae Scientiarum Fennicae. Dissertationes Humanarum Litterarum 34 (or Migration Studies C 6), Turku, 1982, pp. 67-71, 79.

4. For more information, see Esko Ervasti, Suomalainen kirjallisuus ja Nietzsche I. 1900-luvun vaihde ja siïhen välittömästi liittyvät ilmiöt. Annales Universitatis Turkuensis. Ser. B: 77, Turku, 1960, p. 49-52. The Finnish translation of Nietzsche's Also sprach Zarathustra (1884) was published in 1907 (Näin puhui Zarathustra). The translation of Der Antichrist, Versuch einer Kritik der Christentums (1888) (Antikristus. Arvostelukoe kristinopista) appeared in 1908.

5. Köyhälistön Nuïa 1909: M. Hahl, Yli-ihminen, pp. 49-63. Hahl does not specify the Shaw work to which he refers. At question is apparently the 1903 play, "Man and Superman," the Finnish translation of which appeared in 1906.

6. Köyhälistön Nüija 1910: M. Hahl, Kristus, kristitty ja ihminen, pp. 37-69.

7. M. Hahl, Tumma täplä. Yliihminen ja aliihminen, Port Arthur, Ont., 1912.

8. M. Hahl, Lihan evankeliumi. Moraalin arvostelua, Fitchbourg, Mass., 1914.

9. About Nietzsche, see e.g. Tarmo Kunnas, Nietzsche, Zarathustran varjo, Keuruu, 1981.

10. M. Hahl, Kehitysopin aakkoset. Ihanneliittokoulujen ylempiä luokkia ja kotiopetusta varten, Fitchburg, Mass. (n.d., the preface was signed in 1919). Ihanneliitto (Ideal Federations), which operated in conjunction with socialist associations, had as their purpose the enlightenment of youth in the spirit of socialism. On the arrival of Darwinism to Finland, see Pekka Lappalainen, Darwinin teorioiden ja darwinistisen maailmanselityksen tulo Suomeen. Studia Historica Jyväskyläensia V, Historica II, Pieksämäki, 1967.

11. Köyhälistön Nuija 1909: Hahl, pp. 49-63. Some of these ideas are presented by Shaw in the rather extensive "Revolutionist's Handbook" accompanying his play, "Man and Superman."

12. Hahl, Lihan evankeliumi, pp. 4, 12-14, 105.

13. Kunnas, op. cit., esp. pp. 130-138.

14. Hahl's position against violent revolution is set forth, for example in his pamphlet Aseellinen vallankumous, 1910.

15. Hahl, Lihan evankeliumi, pp. 13, 105.

16. Ibid., 105.

17. Ibid،, 78-86.

18. Hahl, Kehitysopin aakkoset, pp. 174-175.

19. Hahl, Tumma täplä; cf. Shaw, op. cit.; see also Raoul Palmgren, Joukkosydän. Vanhan työväenliikkeemme kaunokirjallisuus I, Porvoo, 1966, p. 470.

20. Raivaajan työvainioilta, 1909: M. Hahl, Ilveily järjellä, pp. 10-35. - For more details on Matti Kurikka, see Pilli op. cit., pp. 32-33, 40-57.

21. See Köyhälistön nuïa 1910: Hahl, pp. 37-69, and Hahl, Lihan evankeliumi, pp. 19-63.

22. Hahl, Lihan evankeliumi, pp. 105-106.

23. Ibid., pp. 62-63.

24. Säkeniä 1918, No 8-12: Hijoppi Rotilainen, Kristuksella ratsastava aasi eli Wiljami Tolvana. 
25. M. Hahl, Maansa hylkimiä, Fitchburg, Mass., (n.d.; the preface was signed in 1927).

26. Lehtipaja. Työmiehen neljännesvuosisatajulkaisu, Superior, Wis., 1928: "Feidias" (Kalle Rissanen), Muutamia henkilökuvia, pp. 178-182. 